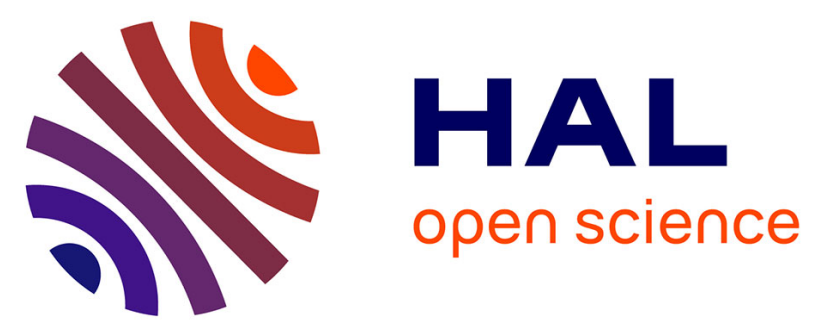

\title{
Two multiple sets of eight and five microsatellite markers for the European corn borer, Ostrinia nubilalis Hübner (Lepidoptera: Crambidae)
}

Ambroise Dalecky, Steven Bogdanowicz, Erik B. Dopman, Denis D. Bourguet, Richard G. Harrison

\section{To cite this version:}

Ambroise Dalecky, Steven Bogdanowicz, Erik B. Dopman, Denis D. Bourguet, Richard G. Harrison. Two multiple sets of eight and five microsatellite markers for the European corn borer, Ostrinia nubilalis Hübner (Lepidoptera: Crambidae). Molecular Ecology Notes, 2006, 6 (3), pp.945-947. 10.1111/j.1471-8286.2006.01410.x . hal-02657465

\section{HAL Id: hal-02657465 \\ https://hal.inrae.fr/hal-02657465}

Submitted on 12 Aug 2020

HAL is a multi-disciplinary open access archive for the deposit and dissemination of scientific research documents, whether they are published or not. The documents may come from teaching and research institutions in France or abroad, or from public or private research centers.
L'archive ouverte pluridisciplinaire HAL, est destinée au dépôt et à la diffusion de documents scientifiques de niveau recherche, publiés ou non, émanant des établissements d'enseignement et de recherche français ou étrangers, des laboratoires publics ou privés.

\section{(c) (1) $\$$}

Distributed under a Creative Commons Attribution - NonCommerciall 4.0 International 


\title{
Two multiplex sets of eight and five microsatellite markers for the European corn borer, Ostrinia nubilalis Hübner (Lepidoptera: Crambidae)
}

\author{
AMBROISE DALECKY ${ }^{*}$ STEVEN M. BOGDANOWICZ,†ERIK B. DOPMAN,†DENIS BOURGUET*and \\ RICHARD G. HARRISON† \\ *Institut National de la Recherche Agronomique (INRA), UMR Centre de Biologie et de Gestion des Populations (CBGP), Campus \\ International de Baillarguet, CS 30016, 34988 Montferrier-sur-Lez cedex, France, +Department of Ecology and Evolutionary Biology, \\ Cornell University, Ithaca, New York 14853, USA
}

\begin{abstract}
Primer sequence and polymorphism data are presented for $\mathbf{1 3}$ microsatellite loci isolated from the European corn borer moth, Ostrinia nubilalis, as part of a project to construct a linkage map for the two pheromone strains. Experimental conditions are described for polymerase chain reaction (PCR) multiplexing, which allows genotyping in two electrophoresis runs of eight and five markers each. In a sample of 27 individuals coming from one European locality, the number of alleles per locus ranged from one to 12, and gene diversity from 0 to 0.859 . Seven loci showed a deficit of heterozygotes. Eleven loci cross-amplify in the related Ostrinia furnacalis.
\end{abstract}

Keywords: dinucleotide microsatellites, European corn borer, Lepidoptera, moth, multiplex PCR, Ostrinia nubilalis, tetranucleotide microsatellite, Zea mays

The European corn borer (ECB), Ostrinia nubilalis Hübner (Lepidoptera: Crambidae), is a Palearctic polyphagous agricultural pest that was introduced to North America in the early 20th century. This extensively studied species includes different pheromone strains (Roelofs et al. 1987) and host races (Malausa et al. 2005), providing a model system for examining the genetic basis of sexual isolation and host-plant specialization. Furthermore, this species is the target of insecticide treatments and transgenic insecticidal maize, which may result in the evolution of resistance if management strategies are not based on knowledge of its population biology (Bourguet 2004). Highly polymorphic genetic markers, such as microsatellite loci, are useful tools for population genetic analyses (Goldstein \& Schlötterer 1999). However, the development of microsatellite markers has been particularly difficult in Lepidoptera (Zhang 2004; Franck et al. 2005; Zhou et al. 2005; references therein) and, until recently, none were available in ECB (Dopman et al. 2004; Coates et al. 2005). Here,

Correspondence: A. Dalecky, Fax: +33 (0)499623345; E-mail: dalecky@ensam.inra.fr and dalecky_am@hotmail.com we present primer sequences, polymerase chain reaction (PCR) conditions and polymorphism statistics for 13 microsatellite markers.

Microsatellite enrichment from genomic DNA is described in Dopman et al. (2004). Approximately 300 positive clones were sequenced and PCR primer pairs were designed for over 200 loci. In ECB, many microsatellite PCRs gave discrete yet multiple products, probably related to redundant flanking sequences across loci within microsatellite DNA families in Lepidoptera (Zhang 2004). This is a more serious deficiency when attempting to assay allelic variation in natural populations, than in building linkage maps. The 13 loci presented in this study are a combination of microsatellites that were either placed on the genetic linkage map described in Dopman et al. (2004), or loci that exhibited 'clean' PCRs but were not segregating in the male-informative and female-informative crosses described in that study (Table 1). In total, we present data for five of the 45 microsatellites used by Dopman et al. (2004) namely D27, D104, D105, D282 and T81 - along with an additional eight loci from the same screening, but which remained unpublished so far. 
Table 1 Primer sequences, PCR conditions and polymorphism statistics for 13 microsatellite loci in one European locality of Ostrinia nubilalis. Linkage groups (i.e. chromosome numbers) as defined by genetic mapping follow Dopman et al. (2004)

\begin{tabular}{|c|c|c|c|c|c|c|c|c|c|c|c|c|c|c|}
\hline PCR no. & Locus & $\begin{array}{l}\text { GenBank } \\
\text { Accession no. }\end{array}$ & Primer sequences $\left(5^{\prime}-3^{\prime}\right)$ & $\begin{array}{l}\text { Repeat } \\
\text { motif }\end{array}$ & $\begin{array}{l}\mu \mathrm{M} \text { each } \\
\text { primer }\end{array}$ & $\begin{array}{l}\text { Linkage } \\
\text { group }\end{array}$ & $\begin{array}{l}\text { Size } \\
\text { range (bp) }\end{array}$ & $n$ & $\begin{array}{l}\text { No. } \\
\text { alleles }\end{array}$ & $f$ & $H_{\mathrm{O}}$ & $H_{\mathrm{E}}$ & $\begin{array}{l}\text { HW } \\
\text { test }\end{array}$ & $\mathrm{ACB}$ \\
\hline \multirow[t]{3}{*}{ PCR-1 } & D9 & DQ354695 & $\begin{array}{l}\text { F: (6-FAM)-CTAGGAACGCCTGGGTCTTCTCATA } \\
\text { R: ACTCGCATGTTCTTTCACAGTATCTTGTATT }\end{array}$ & $\mathrm{AC}$ & 0.2 & 17 & $252-326$ & 24 & 9 & 0.375 & 0.292 & 0.816 & $*$ & $+(276)$ \\
\hline & D77 & DQ354701 & $\begin{array}{l}\text { F: (6-FAM)-CATTCCGCCTCCTCACACTGG } \\
\text { R: GACACCCGCGGGAAGAATAGG }\end{array}$ & AC & 0.2 & ND & $113-120$ & 21 & 4 & 0.500 & 0.381 & 0.595 & & $+(113-117)$ \\
\hline & D104 & DQ354702 & $\begin{array}{l}\text { F: (HEX)-AAATCGCTTCGCTGTGGCTCTT } \\
\text { R: ACGCGTCATGGTGGCTGTGTA }\end{array}$ & AG & 0.2 & 6 & $358-420$ & 22 & 12 & 0.250 & 0.364 & 0.859 & * & - \\
\hline \multirow[t]{5}{*}{ PCR-2 } & D27 & DQ354697 & $\begin{array}{l}\text { F: (HEX)-CGATGGTGGTGTCGCTAGATACTAAAATA } \\
\text { R: GAAGCCACCTAAATTCGAAATCGTTAC }\end{array}$ & $\mathrm{AC}$ & 0.2 & 21 & $173-187$ & 21 & 7 & 0.524 & 0.381 & 0.676 & * & $+(175)$ \\
\hline & D63 & DQ354699 & $\begin{array}{l}\text { F: (NED)-GACCCCGAACCTGGGACTCT } \\
\text { R: CTAGACAAATGCCTTTTAGAAATCTTCAT }\end{array}$ & AG & 0.2 & ND & $96-111$ & 26 & 5 & 0.327 & 0.692 & 0.735 & & $+(101-103)$ \\
\hline & D105 & DQ354703 & $\begin{array}{l}\text { F: (HEX)-AGTCGCCAGTCGCGTTCAATAATAA } \\
\text { R: AAGGCCCAACCCCCAACATAAC }\end{array}$ & $\mathrm{AC}$ & 0.2 & $2+$ & $103-113$ & 13 & 4 & 0.385 & 0.000 & 0.738 & $*$ & $+(103-109)$ \\
\hline & D243 & DQ354705 & $\begin{array}{l}\text { F: (NED)-AAGAATTTTTGAGGTTTATGTTAGTGAT } \\
\text { R: CCAAAGGGCAAGAGGAGAGTA }\end{array}$ & $\mathrm{AC}$ & 0.2 & ND & 328 & 23 & 1 & 1.000 & 0.000 & 0.000 & & $+(328)$ \\
\hline & D282 & DQ354706 & $\begin{array}{l}\text { F: (NED)-ACTCCGCTACTAGAGTGGGATATTGTCAG } \\
\text { R: CAAGGAGACATTATCTTTCGCAGATTTCT }\end{array}$ & $\mathrm{AC}$ & 0.2 & 4 & $248-274$ & 18 & 4 & 0.500 & 0.167 & 0.652 & * & - \\
\hline \multirow[t]{5}{*}{ PCR-3 } & D25 & DQ354696 & $\begin{array}{l}\text { F: (HEX)-GAAGAAAACTCTCCATCGGCACTCT } \\
\text { R: AGTCGGGGAATGGCAATCTATTAGTAAA }\end{array}$ & AG & 0.2 & ND & 73-118 & 23 & 10 & 0.413 & 0.391 & 0.764 & $*$ & $+(79)$ \\
\hline & T81 & DQ354707 & $\begin{array}{l}\text { F: (6-FAM)-AGTGGTTTGGGTTGTGCGTTGATAG } \\
\text { R: GCACTTTATACTCGGGCATGGGTAAT }\end{array}$ & ACTG & 0.1 & $2+$ & 108-179 & 27 & 12 & 0.333 & 0.704 & 0.838 & & $+(112)$ \\
\hline & D65 & DQ354700 & $\begin{array}{l}\text { F: (HEX)-TTGGCGCTTATTTGTTTGTGAA } \\
\text { R: TCCGGTCGCTGCTTGAA }\end{array}$ & AC & 0.2 & 8 & $255-271$ & 27 & 7 & 0.463 & 0.704 & 0.735 & & +261 \\
\hline & D145 & DQ354704 & $\begin{array}{l}\text { F: (NED)-ATTGATCGCCCATGGATAAAGTTCAT } \\
\text { R: ATTTATTTAATTTCTACCTGCTATCACTGCTACTCA }\end{array}$ & $\mathrm{AC}$ & 0.1 & ND & $161-183$ & 26 & 4 & 0.654 & 0.615 & 0.522 & & $+(181-183)$ \\
\hline & D29 & DQ354698 & $\begin{array}{l}\text { F: (6-FAM)-CGGTCAATAGACTCGGTTCACAT } \\
\text { R: ACATAAAATAGTTGCATACATACACAAAAAG }\end{array}$ & GT & 0.2 & ND & $223-243$ & 15 & 6 & 0.567 & 0.133 & 0.662 & $*$ & $+(244)$ \\
\hline
\end{tabular}

t: D105 and T81 are $50 \mathrm{~cm}$ apart.

$n$, number of individuals analysed; $f$, frequency of the most common allele; $H_{\mathrm{O}}$, observed proportion of heterozygous individuals; $H_{\mathrm{E}}$, heterozygosity (i.e. gene diversity; Nei 1987 ); HW test, Hardy-Weinberg exact test (Raymond \& Rousset 1995); *, significant probability test with $\alpha=0.05$ using the sequential Bonferroni correction; ACB, results of cross-species

amplifications using two individuals of the Asian corn borer (Ostrinia furnacalis); -, no amplification detected; +, amplification detected (allele size range between parentheses); ND, not determined. 
PCRs were performed in an MJ Research PTC-200 thermocycler. The forward primer of each pair of microsatellite DNA primers was labelled with a fluorescent dye (Table 1). Multiplex PCR amplifications were carried out for three sets of markers (PCR-1 to PCR-3; Table 1) using Multilocus Amplification Kit (QIAGEN) in a $10-\mu \mathrm{L}$ volume containing $1 \times$ QIAGEN multiplex PCR Master Mix (providing a final concentration of $3 \mathrm{mM} \mathrm{MgCl}_{2}$ ), 0.1-0.2 $\mu \mathrm{M}$ each primer (Table 1) and $2 \mu \mathrm{L}$ of genomic DNA (c. $4 \mathrm{ng}$ DNA/reaction). Cycling conditions were as follows: an initial denaturing step of $15 \mathrm{~min}$ at $94^{\circ} \mathrm{C}$; seven touchdown cycles starting at $94{ }^{\circ} \mathrm{C}(30 \mathrm{~s}), T_{\mathrm{m}}=67^{\circ} \mathrm{C}(90 \mathrm{~s}), 72^{\circ} \mathrm{C}(60 \mathrm{~s})$, $\mathrm{T}_{\mathrm{m}}$ was reduced by $2^{\circ} \mathrm{C}$ per cycle to a temperature of $53^{\circ} \mathrm{C}$; followed by a further 25 cycles at $94{ }^{\circ} \mathrm{C}(30 \mathrm{~s}), 53^{\circ} \mathrm{C}(90 \mathrm{~s})$, $72{ }^{\circ} \mathrm{C}(60 \mathrm{~s})$; and a final extension at $60{ }^{\circ} \mathrm{C}$ for $30 \mathrm{~min}$.

Microsatellite loci were genotyped for 27 diapausing larvae collected in a maize field at Grignon, France (November $\left.2004 ; 48^{\circ} 50.9^{\prime} \mathrm{N}, 01^{\circ} 56.2^{\prime} \mathrm{E}\right)$. DNA was extracted from the head of larvae using the Puregene DNA purification kit (Gentra Systems). PCR products were electrophoresed on an ABI PRISM 310 Genetic Analyser at $60{ }^{\circ} \mathrm{C}$ (injection: $4 \mathrm{~s}$ at $15 \mathrm{kV}$; migration: $27 \mathrm{~min}$ at $15 \mathrm{kV}$ ), using a $20-\mu \mathrm{L}$ volume containing $0.2 \mu \mathrm{L}$ of ROX-60-415-labelled internal marker size standard, $17.8 \mu \mathrm{L}$ of formamide and $2 \mu \mathrm{L}$ of diluted PCR products. Products from PCR-1 and -2 were combined in a first electrophoresis run with $1 \mu \mathrm{L}$ of each PCR at dilution $1 / 100$ and 1/50, respectively. Products of PCR3 were analysed in a second electrophoresis run with $2 \mu \mathrm{L}$ of PCR at dilution 1/100. Alleles were scored by length in base pairs using the GENESCAN and GENOTYPER software.

The levels of polymorphism varied widely among the 13 loci: one locus was monomorphic and for the other 12, the observed number of alleles ranged between four and 12, and gene diversity between 0.522 and 0.859 (Table 1 ). The exact tests for genotypic linkage disequilibrium between pairs of loci (GENEPOP 3.3 package; Raymond \& Rousset 1995) gave significant results $(P<0.05)$ in five out of the 66 tests, although none remained significant after correction for multiple tests (sequential Bonferroni procedure, Rice 1989). The loci were therefore considered to be statistically unlinked. Significant deviations from Hardy-Weinberg equilibrium were detected for seven out of 12 polymorphic loci, and were likely due to null alleles. In agreement with the hypothesis of instability of microsatellite-flanking regions in Lepidoptera (Zhang 2004), a similar proportion of ECB microsatellites with deficit of heterozygote was observed in Coates et al. (2005), suggesting that null alleles may be frequent in this species. Cross-species amplifications were tested on two individuals from the Asian corn borer (Ostrinia furnacalis). This related species amplified successfully for 11 of the 13 microsatellites (Table 1). Including the set of primers developed by Coates et al. (2005), 23 microsatellite markers are now available for genetic analyses of $O$. nubilalis.

\section{Acknowledgements}

We thank M. Galan and A. Loiseau (INRA-CBGP) for help in PCR and multiplexing optimization; Y. Huang (Chinese Academy of Science) for providing DNA samples from Ostrinia furnacalis; and V. Castric for the critical reading of the manuscript. Funding was provided by a grant (2001-35302-11123) to RGH from the US Department of Agriculture National Research Initiative Competitive Grants Program for Entomology and Nematology, and the European Union project 'ProBenBt'.

\section{References}

Bourguet D (2004) Resistance to Bacillus thuringiensis toxins in the European corn borer: what chance for Bt maize? Physiological Entomology, 29, 251-256.

Coates BS, Hellmich RL, Lewis LC (2005) Polymorphic CA/GT and GA/CT microsatellite loci for Ostrinia nubilalis (Lepidoptera: Crambidae). Molecular Ecology Notes, 5, 10-12.

Dopman EB, Bogdanowicz SM, Harrison RG (2004) Genetic mapping of sexual isolation between $\mathrm{E}$ and $\mathrm{Z}$ pheromone strains of the European corn borer (Ostrinia nubilalis). Genetics, 167, 301-309.

Franck P, Guérin F, Loiseau A, Sauphanor B (2005) Isolation and characterization of microsatellite loci in the codling moth Cydia pomonella L. (Lepidoptera, Tortricidae). Molecular Ecology Notes, $5,99-102$.

Goldstein DB, Schlötterer C (1999) Microsatellites: Evolution and Applications. Oxford University Press, Oxford, UK.

Malausa T, Bethenod M-T, Bontemps A et al. (2005) Assortative mating in sympatric host races of the European corn borer. Science, 308, 258-260.

Nei M (1987) Molecular Evolutionary Genetics, 2nd edn. 512 p. Columbia University Press, New York.

Raymond M, Rousset F (1995) GENEPOP (version 1.2): population genetics software for exact tests and ecumenicism. Journal of Heredity, 86, 248-249.

Rice WR (1989) Analyzing tables of statistical tests. Evolution, 43, 223-225.

Roelofs W, Glover T, Tang X-H et al. (1987) Sex pheromone production and perception in European corn borer moths is determined by both autosomal and sex-linked genes. Proceedings of the National Academy of Sciences, USA, 84, 7585-7589.

Zhang DX (2004) Lepidopteran microsatellite DNA: redundant but promising. Trends in Ecology \& Evolution, 10, 507-509.

Zhou Y, Gu H, Dorn S (2005) Isolation of microsatellite loci in the codling moth, Cydia pomonella (Lepidoptera: Tortricidae). Molecular Ecology Notes, 5, 226-227. 